\title{
ANALYSIS OF THE MATERIAL CULTURE AND NEW RADIOCARBON DATING OF THE EARLY NEOLITHIC SITE OF AMNYA I
}

(C) 2019

\author{
Dubovtseva Ekaterina Nikolaevna, researcher of Stone Age Archeology Sector \\ Institute of History and Archaeology of Ural Branch of Russian Academy of Sciences \\ (Ekaterinburg, Russian Federation)
}

Kosinskaya Lubov Lvovna, candidate of historical sciences, senior researcher of Archaeological Research Centre, associate professor of Archaeology and Ethnology Department Ural Federal University named after the first president of Russia B.N. Yeltsin (Ekaterinburg, Russian Federation)

Piezonka Henny, PhD, professor of Anthropological Archeology Department Christian-Albrechts University of Kiel (Kiel, Federal Republic of Germany)

Abstract. The ancient fortified settlement of Amnya I is a unique Early Neolithic site in the northern taiga zone of Western Siberia (Khanty-Mansi Autonomous Okrug, the Amnya river). It is located on a promontory and has three lines of defense and ten dwelling depressions. The structures of the excavated dwellings are very similar, though the artifact assemblage appears rather heterogeneous. We carried out a technical and technological analysis of ceramics, which showed no correlation between the texture, on the one hand, and the morphology and ornamentation of pots on the other one. Planiographic analysis of ceramics showed that vessels with comb and incising patterns are found in different dwellings, although there are objects in which both groups lie together. Various categories of stone implements (bladelets and polished arrowheads) also appear on different parts of the settlement. Most likely, the observed differences in the artefact complexes of objects are associated with the stages of the functioning of the settlement. The absolute chronology does not yet clarify the sequence of erection and existence of objects. New AMS date is probably vulnerable to a significant reservoir effect. The abundance of unsolved issues of absolute and relative chronology makes the resumption of research on this unique site urgent.

Keywords: Western Siberia; Lower Ob basin; taiga zone; Early Neolithic; promontory fort; ceramics; lithic inventory; dwellings; radiocarbon dating; planographic analysis; technical and technological analysis of ceramics; technomorphological analysis of lithic inventory.

УДК 902, 903

DOI 10.24411/2309-4370-2019-12211

Статья поступила в редакцию 15.02.2019

\section{СОВРЕМЕННЫЕ ПРЕДСТАВЛЕНИЯ О КУЛЬТУРАХ НЕОЛИТА НА СЕВЕРО-ВОСТОКЕ ЕВРОПЫ}

Карманов Виктор Николаевич, кандидат исторических наук, заведующий сектором сохранения и популяризации археологического наследия Институт языка, литературы и истории Коми научного центра УрО РАН

(2. Сыктывкар, Российская Федерачия)

Недомолкина Надежда Геннадьевна, кандидат исторических наук, ведущий научный сотрудник отдела фондов

Вологодский государственньй историко-архитектурный и художественный музей-заповедник

(2. Вологда, Российская Федерация)

Мельничук Андрей Фёдорович, кандидат исторических наук, доцент кафедры древней и новой истории России Пермский государственный национальный исследовательский университет (2. Пермь, Российская Федерация)

\footnotetext{
Аннотация. В статье обобщены и систематизированы сведения о культурах неолита на северо-востоке Европы - современной территории Республики Коми, северной части Пермского края, Вологодской и Архангельской областей, Ненецкого АО. На основе критики опорных источников, их анализа и интерпретации авторы представляют свою точку зрения на особенности формирования, развития и дальнейшей судьбы культур неолита региона. Установлено, что в регионе располагаются северные и северо-восточные провинции известных культур раннего и среднего неолита Восточной Европы - верхневолжской, камской, льяловской и родственной ей каргопольской. Кроме того, выявлены фрагменты культур, исходные территории формирования которых пока достоверно не определены. Их представляют ранненеолитические памятники типа Дутово 1, Черноборской III, Эньты IA и Черной Вадьи. Некоторые типы керамической посуды без определенного контекста документируют присутствие на северо-востоке Европы групп населения, статус которых пока не определен. Авторы предполагают, что формирование культур неолита в регионе связано с поиском неосвоенных кормовых территорий, их освоением и кратковременной эксплуатацией небольшими группами людей, соизмеримых с элементарными или объединенными семьями. На большей территории СВЕ за исключением ее самых юго-западных и юго-восточных частей, условия для длительного проживания первобытного населения и формирования местных традиций отсутствовали вплоть до энеолита.

Ключевые слова: археология; неолит; северо-восток Европы; палеогеография; археологическая культура; археологические источники; археологический контекст; археологические разведки; археологические раскопки; миграции; каменный инвентарь; керамическая посуда; стоянка; поселение; многослойный памятник; углубленное жилище; скопление; очаг.
} 


\section{Введение}

В разные годы исследователи предложили локальные схемы развития культур неолита северовостока Европы (далее СВЕ). Согласованность этих схем обеспечивали взаимные аналогии материалов сопредельных территорий, но в большей мере получаемые данные представляли несобранные «пазлы». Напротив, обобщающие исследования вынужденно $[1$, c. 210-252] содержали сведения энциклопедического характера и создавали картины с низким разрешением. В предыдущих работах авторы уже опубликовали результаты анализа инвентарей памятников неолита СBE и их контекстов и попытались определить их культурную атрибуцию, хронологию и место в системе культур неолита Северной Евразии $[2$, с. $21-31 ; 3$, с. $265-279 ; 4$, с. $2-20 ; 5$, с. $79-87 ; 6$, c. $12-18 ; 7$, c. $26-73 ; 8$, c. $153-168 ; 9$, c. $66-71 ; 10$, c. $84-104 ; 11$, с. $66-71 ; 12$, с. 49-50]. Открытия последних лет; осознание необходимости применения независимых методов датирования и их лучшая доступность; оперативная публикация новейших результатов позволили конкретизировать существовавшие ранее представления и получить новые данные об особенностях формирования, развития и дальнейшей судьбы культур неолита региона на основе критики источников, их анализа и интерпретации. В этой статье мы попытаемся соединить несколько разных представлений об этом, пока лишь в одну из больших деталей общей картины. Задачи исследования: характеристика географии района исследования и истории его изучения; систематизация источников по их познавательным возможностям.

\section{Характеристика района исследований}

$\mathrm{CBE}$ - регион, ограниченный на севере побережьями Баренцева и Белого морей; на востоке - Уральским хребтом. На юге его граница проходит по широте городов Вологды и Березников, а на западе по долготе городов Вологды и Северодвинска. Крайняя северная часть региона располагается в зоне тундры, южная - приурочена к северной тайге. В геоморфологическом отношении его большая часть находится на Восточно-Европейской Равнине, восточная окраина представлена предгорьями Урала. Административно район исследования приурочен к современной территории Республики Коми, северной части Пермского края, Вологодской и Архангельской областей, Ненецкого АО.

Известные опорные источники для изучения неолита выявлены исключительно в таежной зоне, занятой преимущественно девственными лесами (около 60\%), болотами (около 14\%) и густой речной сетью бассейнов четырех рек: Печоры, Мезени, Северной Двины и, частично Волги с Камой. При этом ее отличает крайняя малочисленность озёр. Например, на территории Республики Коми их суммарная площадь составляет около $0,1 \%$ или 450 тыс. га всего 1/20 Онежского озера.

По данным палеогеографии СВЕ и в бореальный, и в атлантический периоды входил в зону темнохвойной тайги, смещались лишь границы ландшафтных подзон - средней и южной тайги [13, c. 154-162] или структура растительного покрова менялась в основном за счет количественного перераспределения внутри группы хвойных пород [14, c. 2-17]. В частности, в долине р. Вычегды в атлантический период шло дальнейшее развитие хвойных с незначительными примесями широколиственных лесов (главным образом вяза) [15; 16, с. 2-40]. В бассейне р. Вятки на южной окраине СВЕ «...за все послеледниковое время широколиственные породы ... не имели доминирующего значения. Наиболее значительные массивы широколиственных лесов могли быть приурочены лишь к поймам крупных рек ...» $[17$, с. $68-70]$. Таким образом, биологическая емкость ландшафта менялась незначительно. Об этом свидетельствует и состав фауны. Показательно сравнение между коллекциями памятников крайней северо-восточной части и ее самого юго-западного контекста Вёкса III. В разных слоях этого памятника выявлено разнообразие фауны, включающих остатки лося, бобра, благородного оленя, кабана, косули, тура или зубра [18, с. 81 , рис. 7]. При этом на стоянках р. Вычегды остеологические материалы ограничены преимущественно северным оленем, лосем и бобром $[19$, с. 425 , табл. 1].

\section{История представлений}

Разрозненные сведения о находках неолита из разных частей CBE стали поступать еще в конце XIX в. Лишь в 1920-30-е гг. его отдельные территории стали исследоваться профессиональными археологами (М.Е. Арсакова, И.К. Цветкова, А.Я. Брюсов, М.Е. Фосс). В конце 1940-х - начале 1950-х гг. это позволило М.Е. Фосс впервые обобщить и систематизировать доступные материалы. В западной части региона ею были обособлены памятники каргопольской и беломорской культур, которые складывались на основе традиций культур ямочно-гребенчатой керамики. Известные памятники бассейна р. Печоры она отнесла к печорской культуре, имеющей местное происхождение [20, с. 248-253]. Опираясь на немногочисленные и разрозненные данные, исследователь предположила, что регион сравнительно поздно и слабо осваивался в кон. II - перв. пол. I тыс. до н.э., а материалы известных неолитических культур здесь отсутствуют [21, с. 29-46]. Лишь в 1957 г. инвентарь стоянки Печорская с гребенчато-ямочной керамикой льяловского типа позволил Н.Н. Гуриной «уточнить вопрос первичного заселения Печорского края, устанавливая наличие более раннего этапа его древней истории» [22, с. 120]. Северную часть Пермского края с верхним течением р. Камы и ее притоками впервые обследовал в 1949 г. О.Н. Бадер [23, с. 241258]. Но ему среди прочих материалов удалось выявить лишь обломки керамической посуды, которые он сопоставил с керамикой лёвшинского этапа камской культуры неолита.

В результате последующих исследований Г.М. Бурова $[24$, с. $69-93 ; 25$, с. $18-81]$, В.Е. Лузгина [26, с. $97-98 ; 27$, с. $22-34]$, В.П. Денисова [28, с. $34-71$; 29 , с. 312-327], С.В. Ошибкиной [30], Э.С. Логиновой $[31$, с. $3-23 ; 32$, с. 66], В.С. Стоколоса [33, с. 31-36; 34, с. 16-26], И.В. Верещагиной [35, с. 2953], Л.Л. Косинской [36, с. 132-144; 37, с. 10-16; 38, с. 224-231; 39, с. 39-54], М.В. Иванищевой [40, с. 85105], Н.Г. Недомолкиной [4, с. 2-18; 6, с. 12-18], В.Н. Карманова [7], А.Ф. Мельничука [2, с. 21-31; 11, с. 66-71] в 1950-х - 2010-х годах было определено многообразие культур населения эпохи неолита на CBE. Особенно активно в эти годы изучаются современные территории Пермского края, Республики Коми, Вологодской и крайней западной части Архангельской областей, некоторых участков восточной окраины Архангельской области и Ненецкого АО. 
Карманов В.Н., Недомолкина Н.Г., Мельничук А.Ф.

Еще в 1960-х гг. потеряли актуальность представления о беломорской и печорской культурах. В 1978 г. С.В. Ошибкина представила обновленную концепцию каргопольской культуры [30, с. 140-158], но с этого времени аналогичные по интенсивности исследования памятников неолита с тех пор здесь не проводились. Хотя сплошными разведками в Восточном Прионежье было выявлено множество местонахождений с обломками керамики неолита [41, c. 310-387].

Последующее изучение верхнего течения р. Камы с притоками, не затронутого негативным воздействием сооружения Камского водохранилища, возобновил во второй половине 1990-х гг. А.Ф. Мельничук. С небольшими перерывами это исследование продолжается до настоящего времени $[12$, с. 49]. В результате выявлено соответствие материалов региона камской культуре гребенчатой керамики и волгокамской культуре с накольчатой керамикой; поставлен вопрос о присутствии здесь носителей культуры ямочно-гребенчатой керамики и посуды эньтыйского и висского типов $[11$, с. $67-68]$.

Особенно активно исследования по систематизации и обобщению данных по неолиту проводились на территории Республики Коми. В 1967-2008 гг. были представлены различные концепции формирования и развития культур этого региона, которые неоднократно корректировались, дополнялись, в том числе самими исследователями, их предложившими $[24$, с. $166-168 ; 25$, с. $88-102 ; 42$, с. $9-13 ; 35$, с. $47-$ 53 ; 43 , c. $6-18 ; 44$, c. $146-212 ; 10$, c. $84-104 ; 7$, c. $56-$ $80 ; 19$, c. $419-446 ; 45$, c. $331-339 ; 46$, c. $733-741]$.

Несмотря на различия во взглядах на происхождение, развитие и дальнейшую судьбу носителей культур неолита, можно определить четыре основные концепции, предложенные исследователями. Длительное автохтонное развитие населения неолита на отдельных территориях CBE с периодическими влияниями культур сопредельных территорий предлагали М.Е. Фосс [20, с. 204, 205] и О.Н. Бадер [47, c. 105,106$]$. Концепцию сегментации неолитических племен и их дальнейшее расселение вслед за А.Я. Брюсовым предложил в 1967 г. Г.М. Буров [24, с. 166-168]. Впоследствии его поддержала И.В. Верещагина $[48$, с. $17-18 ; 35$, с. 47-53]. По мнению исследователей в контактных зонах мигранты - носители разных традиций - взаимодействовали, формируя новые культуры. В 1997 г. Л.Л. Косинская, отрицая большую роль миграционного фактора, представила концепцию единого культурного поля, пронизанного разнообразными культурными связями, налаженными еще в мезолите. Исследователь допускала миграции лишь в исключительных случаях, например, для появления в регионе своеобразной индустрии эньтыйского типа [44, с. 185-187]. В 2004 г. В.Н. Карманов предложил иную точку зрения, согласно которой освоение региона в неолите ограничено кратковременной эксплуатацией его промысловых ресурсов небольшими группами охотниковсобирателей. $\mathrm{CBE}$ являлся частью территории природопользования населения культур, основной ареал которых расположен южнее. Благодаря его периферийности, удалось зафиксировать конечные отрезки путей миграций носителей различных культур [7, c. 74-81]. К сожалению, сопредельные территории расположены в менее благоприятной источниковедческой ситуации, и материалы, документирующие конкретные и полные аналогии, зачастую теряются в массивах данных этих более плотно заселенных регионов [19, с. 614-626].

В настоящее время районы СВЕ в части выявления и стационарных раскопок памятников неолита изучены неравнозначно. Картирование известных местонахождений показывает наличие, по крайней мере, пяти крупных «белых пятен»: междуречья Онеги и Северной Двины; Мезени и Северной Двины (Архангельская область); левобережная часть бассейна р. Печоры (центральная часть Республики Коми); практически вся Большеземельская тундра (Ненецкий $\mathrm{AO}$ и северо-восток Республики Коми); верхние части рек бассейна р. Волги - Камы, Вятки и верховья рек Северодвинского бассейна (части Костромской, Кировской и Пермского края и юг Республики Коми). Некоторые из этих областей археологическими разведками обследованы многократно (например, долины Ижмы и Печоры; Большеземельская тундра; Коми-Пермяцкий округ Пермского края) и отсутствие информативных памятников неолита на них предположительно объективно. Другие регионы (части Архангельской и Кировской областей) обследованы слабо и вероятность обнаружения на них новых неолитических местонахождений высока. Эти обстоятельства, несомненно, следует иметь в виду при характеристике ареалов культур неолита в регионе.

\section{Систематизачия источников}

По степени изученности выделяется три группы источников для изучения неолита СВЕ. В первую входят материалы, сопоставимые с известными культурами этого периода; во вторую - памятники, объединенные общностью традиций камнеобработки и изготовления орудий, в т.ч. керамической посуды, но не находящих полного соответствия в материалах сопредельных регионов. В третью - отдельные типы керамической посуды, которые с большей степенью вероятности относятся к неолиту, но не обеспечень никакими другими категориями источников. С памятниками первой группы все определенно, их статус уже установлен и материалы СВЕ лишь расширяют представления о них. С третьей группой тоже все ясно. Это пока лишь уровень типов керамической посуды, документирующих следы пребывания некоего эфемерного неолитического населения, судьба которого, возможно, решится в будущем.

Основная сложность возникает при атрибуции второй группы источников, которые исследователи обособляют в виде культурных типов, типов или групп памятников. Как неопределенны их ареалы (это редкие точки в пространстве) и зачастую их хронология, так и неопределенна их атрибуция. Можно предположить, что эти памятники могут документировать фрагменты культур, сведения о которых пока отрывочны, их предыстория, судьба и исходный ареал формирования пока не определен. Но никакое явление в первобытности не могло возникнуть вдруг и сразу. У каждого даже малочисленного коллектива, который оставил следы своей жизнедеятельности на изученной нами стоянке есть своя история, из которой нам доступен лишь очень маленький отрывок. Поэтому в нашем исследовании мы будем понимать их как особые культуры с осознанием фрагментарности источников для их изучения.

Кроме того, можно предположить, что все выделяемые нами культуры неолита - лишь вариации общей первобытной культуры таёжных охотниковсобирателей, и среди них общих признаков гораздо 
Карманов В.Н., Недомолкина Н.Г., Мельничук А.Ф.

Современные представления о культурах неолита на северо-востоке.

07.00.00 - исторические науки и археология

больше, чем отличий. Поэтому наша работа по выявлению специфики каждой из них идет в очень узком диапазоне.

В настоящее время мы можем утверждать о периодичности заселения региона: уверенно выделяется два периода и менее достоверны и информативны сведения о третьем этапе освоения СВЕ. Отметим, что в работе мы вынужденно используем трехчастную периодизацию неолита, поскольку понимаем, что доступные источники пока не дают оснований для переоценки существующих представлений.

\section{Ранний период}

Этот период соответствует VI тыс. до н.э. (здесь и далее по тексту мы будем приводить календарный возраст с учетом калиброванных значений имеющихся радиоуглеродных дат. Калибровка производилась в программе OxCal, v.4.3; калибровочная кривая IntCal 13, доступная по адресу https://c14.arch.ox.ac. uk/oxcal/OxCal.html). K нему на CBE относятся pacсеянные следы пребывания небольших групп носителей шести разных культур, представленных памятниками верхневолжской и камской культур, стоянками типа Дутово 1, Черноборская III, Черная Вадья и Эньты IA.

Верхневолжская культура на ее древнейшем этапе развития в полной мере представлена лишь на одном памятнике - Зубово на р. Мезени [9, с. 66-71]. На других поселениях - Вёкса и Вёкса III [49, с. 427]; Явроньга I [25, с. 36-38]; Вис I и II [24, с. 112-115] с разной степенью уверенности определены лишь обломки керамических сосудов без достоверной связи с другими категориями источников. Такие скудные данные не позволяют корректно характеризовать особенности формирования ареала верхневолжской культуры на СВЕ. Можно лишь предположить, что известные источники - следы эпизодических миграций небольших по численности групп. Время бытования этих памятников может быть установлено только на основании аналогий с памятниками с накольчатой или тычковой орнаментацией сопредельных территорий. С наибольшей степенью вероятности это первая половина VI тыс. до н.э. [50, c. $19-20 ; 51$, с. 1045-1046; 52, с. 159-160).

Второй или третий этап верхневолжской культуры представлен на СВЕ только керамической посудой и только на памятниках эньтыйского типа Эньты IA [31, с. 5-14; 7, с. 38-43, 63-65]; Вёкса-Н и Вёкса III (слой 9) [3, с. 268-271]. Однако каменный инвентарь, содержащий серии из десятков геометрических микролитов в форме трапеций не позволяет соотнести такие материалы с этой культурой в полной мере. Аналогичные характеристики имеет кремневая индустрия всего одного памятника - Ревью I на р. Вычегде, однако, керамика в этом контексте не обнаружена [39, с. 39-54]. Кроме того, трапеции эньтыйского типа выявлены в коллекции многокомпонентных памятников Березовая Слободка II-III (p. Сухона, Вологодская область) [40, с. 102, рис. 9], и в разведочных материалах стоянки Усть-Дароватка. Единичные геометрические микролиты этого типа найдены и на других памятниках Вологодской области $[53$, c. 147,148$]$. Истоки такой традиции пока достоверно не установлены, но само явление не могло возникнуть ниоткуда и внезапно и, поэтому можно предположить, что мы фиксируем следы отрезка миграционного пути носителей таких традиций в регион или через него. Хронология этого события может быть определена на основе сравнительного анализа с материалами второго или третьего этапа верхневолжской культуры, а также серии дат из контекстов Вёксы III и Ревью I (табл. 1). Правда, разброс дат получился широким и включает период рубежа VII-VI - первой половины V тыс. до н.э., с большей степенью вероятности второй половины VI тыс. до н.э. Памятники исходной территории формирования верхневолжской культуры на финальном этапе ее развития датируются третьей четвертью - концом VI тыс. до н.э. [50, с. $20 ; 52$, с. 160$]$.

Камскую культуру на СВЕ в полной мере представляют контексты стоянок Хомутовское болото 1 и 2, Нюхти 1 и 2 (долина р. Вишеры, Пермский край). Наиболее информативны материалы Нюхти 1, которые включают однородный каменный инвентарь и три типа посуды, орнаментированные оттисками гребенчатого штампа, наколами и насечками. Последние два в мотивах и композициях имитируют оттиски зубчатого орнаментира Полным аналогом этих материалов является поселение Кочуровское I в подбассейне р. Вятки, хотя территориально близкое к р. Каме. Здесь в контексте жилища совместно залегали три разных типа керамической посуды при однородном каменном инвентаре камской культуры [54, с. 87-91].

Далее на северо-восток местонахождения раннего этапа камской культуры содержат преимущественно единичные и фрагментарные сосуды без определенных контекстов и обеспечения другими категориями источников. Это стоянки бассейна р. Вычегды Себъяг I, Усть-Кулом I, Эньты I, III, V [7, с. 43-45], Вис I и II $[24$, с. 69,70$]$ (Республика Коми) и наиболее удаленный памятник - поселение Явроньга I [25, c. 51] в подбассейне р. Пинеги (Архангельская область). Выделяются два вычегодских памятника Кочмас Б [37, с. 10-16] и Пезмог IV [46, с. 733-741]. На первом памятнике найдены изделия из кремня и некремневых пород, реконструируемые сосуды, остатки фауны и следы земляной структуры. Но он частично поврежден боковой эрозией р. Вычегды и, к сожалению, кремневый инвентарь памятника малоинформативен, и не содержит типы орудий, характерные для камской культуры. Это можно объяснить тем, что на р. Вычегде нет источников плитчатого кремня, на котором базируется каменная индустрия этой культуры, и коллективы вынуждены были адаптироваться к региональным особенностям сырьевой базы. Но не исключено, что керамическая посуда на этом памятнике, да и на других тоже - результат брачных связей, только вот кто мог устанавливать такие связи с носителями керамических традиций камской культуры пока неизвестно, поскольку данные о других категориях источников, в т.ч. каменном инвентаре не информативны или отсутствуют вовсе. Другой контекст - Пезмог IV - содержал единичный сосуд хорошей сохранности в погребенном аллювием состоянии на глубине 3,6-3,8 м. Наличие нагара и большого количества разного вида органических образцов в культуровмещающих и вышележащих отложениях позволили достоверно установить его ранненеолитический возраст в рамках второй четверти VI тыс. до н.э. (табл. 1). Вместе с этим появилась возможность удревнить и ранний этап самой камской культуры, синхронизировав его тем самым с древнейшей гребенчатой керамикой еттовского типа Западной Сибири [55, с. 30-40]. 
Карманов В.Н., Недомолкина Н.Г., Мельничук А.Ф.

07.00.00 - исторические науки и археология Современные представления о культурах неолита на северо-востоке.

Таблица 1 - Радиоуглеродные даты памятников северо-востока Европы

\begin{tabular}{|c|c|c|c|c|c|}
\hline Памятник & $\begin{array}{c}\text { Контекст; } \\
\text { датированный материал }\end{array}$ & $\begin{array}{c}\text { Индекс } \\
\text { лаборатории }\end{array}$ & $\begin{array}{l}{ }^{14} \mathrm{C} \mathrm{л.н.} \\
\text { (ВР) }\end{array}$ & $\begin{array}{c}\text { Калиброванная } \\
\text { дата (вероят- } \\
\text { ность } 95,4 \%), \text { гг. } \\
\text { до н.э. (cal BC) }\end{array}$ & Источник \\
\hline \multicolumn{6}{|c|}{ Контексты, сопряженные с верхневолжской культурой } \\
\hline Вёкса III & $\begin{array}{l}\text { Раскоп } 12015 \text { г., слой 9; } \\
\text { кв. L-167; сосуд № 2015/17; на- } \\
\text { гар на внутренней поверхности }\end{array}$ & MAMS-25493 & $6677 \pm 25$ & $5641-5551$ & $\begin{array}{l}49, \text { с. } 431- \\
433, \text { табл. } 1\end{array}$ \\
\hline Вёкса III & $\begin{array}{l}\text { Раскоп } 2000 \text { г., слой 9; кв. 170-И; } \\
\text { грунт с древесными углями }\end{array}$ & Лe-5866 & $6950 \pm 150$ & $6201-5562$ & $\begin{array}{l}49, \text { с. } 431- \\
433, \text { табл. } 1\end{array}$ \\
\hline \multicolumn{6}{|c|}{ Контексты, сопряженные с верхневолжской культурой и эньтыйским типом } \\
\hline Вёкса III & $\begin{array}{l}\text { Раскоп } 2000 \text { г., слой 9; кв. 167-3; } \\
\text { яма; грунт с древесными углями }\end{array}$ & Лe-5864 & $6730 \pm 160$ & $5980-5376$ & $\begin{array}{l}49, \text { с. } 431- \\
433, \text { табл. } 1\end{array}$ \\
\hline Вёкса III & $\begin{array}{l}\text { Раскоп } 2000 \text { г., слой 9; кв. 171-И; } \\
\text { ямка; грунт с древесными углями }\end{array}$ & Лe-5869 & $6650 \pm 200$ & $5982-5223$ & $\begin{array}{l}49, \text { с. } 431- \\
433, \text { табл. } 1 \\
\end{array}$ \\
\hline Вёкса III & $\begin{array}{l}\text { Раскоп } 1997 \text { г., кв. 167; грунт с } \\
\text { древесными углями }\end{array}$ & ГИН-10181 & $6500 \pm 170$ & $5735-5059$ & $\begin{array}{l}49, \text { с. } 431- \\
433, \text { табл. } 1\end{array}$ \\
\hline Вёкса III & $\begin{array}{l}\text { Раскоп } 2000 \text { г., слой 9; кв. 171-И; } \\
\text { грунт с древесными углями }\end{array}$ & Лe-5870 & $6400 \pm 130$ & $5616-5060$ & $\begin{array}{l}49, \text { с. } 431- \\
433, \text { табл. } 1\end{array}$ \\
\hline Вёкса III & $\begin{array}{l}\text { Подъемный материал } 1996 \text { г.; } \\
\text { сосуд керамический; нагар } \\
\text { на внутренней поверхности }\end{array}$ & KIA-49797 & $6386 \pm 21$ & $5466-5316$ & $\begin{array}{l}49, \text { с. } 431- \\
433, \text { табл. } 1\end{array}$ \\
\hline Вёкса III & $\begin{array}{l}\text { Раскоп } 2002 \text { г., слой 9; ямка; } \\
\text { грунт с древесными углями }\end{array}$ & KIA-33929 & $6340 \pm 30$ & $5460-5223$ & $\begin{array}{l}49, \text { с. } 431- \\
433, \text { табл. } 1\end{array}$ \\
\hline Вёкса III & \begin{tabular}{|l|} 
Подъемный материал; \\
сосуд № 2007/115; нагар \\
на внутренней поверхности
\end{tabular} & KIA-49798 & $6314 \pm 22$ & $5340-5221$ & $\begin{array}{l}49, \text { с. } 431- \\
433, \text { табл. } 1\end{array}$ \\
\hline Вёкса III & $\begin{array}{l}\text { Раскоп } 2000 \text { г., слой 9; кв. 168-И; } \\
\text { кострище; древесный уголь }\end{array}$ & Лe-5868 & $6220 \pm 150$ & $5478-4807$ & $\begin{array}{l}49, \text { с. } 431- \\
433, \text { табл. } 1\end{array}$ \\
\hline Эньты IA & Керамика, прямое датирование & $\mathrm{Ki}-16032$ & $4930 \pm 80$ & $3947-3536$ & $\begin{array}{c}45, \text { с. } 334 \\
\text { табл. } 1 \\
\end{array}$ \\
\hline Эньты IA & Керамика, прямое датирование & $\mathrm{Ki}-15534$ & $5625 \pm 80$ & $4680-4337$ & $\begin{array}{l}45, \text { c. } 334, \\
\text { табл. } 1\end{array}$ \\
\hline Ревью I & Яма № 5; костный уголь & ГИН-15746 & $5910 \pm 90$ & $5001-4549$ & 39, c. 43 \\
\hline \multicolumn{6}{|c|}{ Камская культура } \\
\hline Пезмог IV & $\begin{array}{l}\text { Раскоп, } 1999 \text { г.; керамический } \\
\text { сосуд; нагар на внутренней по- } \\
\text { верхности }\end{array}$ & ГИН-11915 & $6820 \pm 70$ & $5876-5618$ & $\begin{array}{l}45, \text { c. } 334, \\
\text { табл. } 1\end{array}$ \\
\hline Пезмог IV & $\begin{array}{l}\text { Раскоп, } 1999 \text { г.; } \\
\text { древесный уголь в культу- } \\
\text { ровмещающих отложениях }\end{array}$ & ГИН-12324 & $6760 \pm 50$ & $5736-5569$ & $\begin{array}{l}45, \text { c. } 334, \\
\text { табл. } 1\end{array}$ \\
\hline Пезмог IV & $\begin{array}{l}\text { Раскоп, } 1999 \text { г.; культуровмеща- } \\
\text { ющие отложения }\end{array}$ & ГИН-12322 & $6730 \pm 50$ & $5725-5559$ & $\begin{array}{l}\text { 45, с. } 334, \\
\text { табл. } 1\end{array}$ \\
\hline Пезмог IV & Керамика, прямое датирование & $\mathrm{Ki}-15428-2$ & $6130 \pm 100$ & $5308-4807$ & $\begin{array}{c}45, \text { с. } 334 \\
\text { табл. } 1\end{array}$ \\
\hline Пезмог IV & Керамика, прямое датирование & $\mathrm{Ki}-15428-1$ & $6410 \pm 90$ & $5544-5214$ & $\begin{array}{c}45, \text { с. } 334, \\
\text { табл. } 1\end{array}$ \\
\hline Хуторская & Жилище № 1; керамика & $\mathrm{Ki}-14414$ & $5930 \pm 80$ & $5016-4604$ & $\begin{array}{l}\text { 56, с. } 153, \\
\text { табл. } 1 \\
\end{array}$ \\
\hline Хуторская & Жилище № 2; керамика & $\mathrm{Ki}-14420$ & $5920 \pm 90$ & $5016-4553$ & $\begin{array}{l}56, \text { с. } 153, \\
\text { табл. } 1 \\
\end{array}$ \\
\hline Хуторская & Раскопки 2006 г.; керамика & $\mathrm{Ki}-14419$ & $5840 \pm 80$ & $4901-4499$ & $\begin{array}{c}56, \text { с. } 153 \\
\text { табл. } 1 \\
\end{array}$ \\
\hline Хуторская & Жилище № 1; керамика & $\mathrm{Ki}-15093$ & $5750 \pm 80$ & $4791-4402$ & $\begin{array}{l}\text { 56, с. } 153, \\
\text { табл. } 1\end{array}$ \\
\hline Васюково II & Керамика & $\mathrm{Ki}-16857$ & $5270 \pm 80$ & $4325-3957$ & $\begin{array}{c}56, \text { с. } 155, \\
\text { табл. } 1 \\
\end{array}$ \\
\hline Хуторская & Уголь древесный & ГИН-14226 & $5130 \pm 250$ & $4486-3372$ & $\begin{array}{c}56, \text { с. } 153 \\
\text { табл. } 1 \\
\end{array}$ \\
\hline Хуторская & Уголь древесный & COAH-6817 & $5040 \pm 130$ & $4228-3536$ & $\begin{array}{c}\text { 56, с. } 153, \\
\text { табл. } 1 \\
\end{array}$ \\
\hline Хуторская & Уголь древесный & COAH-6818 & $4990 \pm 110$ & $4038-3533$ & $\begin{array}{l}\text { 56, с. } 153, \\
\text { табл. } 1\end{array}$ \\
\hline
\end{tabular}


Карманов В.Н., Недомолкина Н.Г., Мельничук А.Ф.

Современные представления о культурах неолита на северо-востоке..

07.00.00 - исторические науки и археология

\begin{tabular}{|c|c|c|c|c|c|}
\hline Памятник & $\begin{array}{c}\text { Контекст; } \\
\text { датированный материал }\end{array}$ & $\begin{array}{c}\text { Индекс } \\
\text { лаборатории }\end{array}$ & $\begin{array}{l}{ }^{14} \mathrm{C} \text { л.н. } \\
\text { (ВР) }\end{array}$ & $\begin{array}{c}\text { Калиброванная } \\
\text { дата (вероят- } \\
\text { ность 95,4\%), гг. } \\
\text { до н.э. (cal BC) }\end{array}$ & Источник \\
\hline \multicolumn{6}{|c|}{ Второй комплекс с гребенчатой керамикой Вёксы III } \\
\hline Вёкса III & $\begin{array}{l}\text { Подъемный материал } 1996 \text { г., } \\
\text { сосуд № 2007/112; } \\
\text { нагар на керамическом сосуде }\end{array}$ & KIA-49799 & $6285 \pm 30$ & $5317-5216$ & $\begin{array}{l}49, \text { с. } 431- \\
433, \text { табл. } 1\end{array}$ \\
\hline Вёкса III & $\begin{array}{l}\text { Раскоп } 2000 \text { г., слой } 8, \text { кв. 169-И; } \\
\text { грунт с древесными углями }\end{array}$ & Лe-5856 & $6200 \pm 170$ & $5482-4729$ & $\begin{array}{l}49, \text { с. } 431- \\
433, \text { табл. } 1\end{array}$ \\
\hline Вёкса III & $\begin{array}{l}\text { Подъемный материал } 1996 \text { г., } \\
\text { сосуд № 2007/111; } \\
\text { нагар на керамическом сосуде }\end{array}$ & KIA-33927 & $6185 \pm 30$ & $5222-5041$ & $\begin{array}{l}49, \text { с. } 431- \\
433, \text { табл. } 1\end{array}$ \\
\hline \multicolumn{6}{|c|}{ Контексты, сопряженные с льяловской культурой } \\
\hline $\begin{array}{l}\text { Вёкса I, кера- } \\
\text { мика льялов- } \\
\text { ского типа }\end{array}$ & $\begin{array}{l}\text { Сосуд, закопанный на береговом } \\
\text { склоне, } 9 \text { участок поселения; } \\
\text { нагар на керамическом сосуде }\end{array}$ & $\mathrm{SPb}-1691$ & $5843 \pm 80$ & $4903-4502$ & $\begin{array}{l}49, \text { с. } 431- \\
433, \text { табл. } 1\end{array}$ \\
\hline $\begin{array}{l}\text { Пезмогты } 1, \\
\text { керамика лья- } \\
\text { ловского типа } \\
\end{array}$ & Кострище; древесный уголь & ГИН-11914 & $5840 \pm 100$ & $4941-4464$ & $\begin{array}{c}45, \text { с. } 334 \\
\text { табл. } 1\end{array}$ \\
\hline $\begin{array}{l}\text { Пезмогты } 1, \\
\text { керамика лья- } \\
\text { ловского типа } \\
\end{array}$ & Керамика, прямое датирование & $\mathrm{Ki}-16657$ & $5690 \pm 80$ & $4706-4365$ & $\begin{array}{l}45, \text { с. } 334, \\
\text { табл. } 1\end{array}$ \\
\hline $\begin{array}{l}\text { Вёкса III; ке- } \\
\text { рамика «се- } \\
\text { верного типа» } \\
\end{array}$ & $\begin{array}{l}\text { Подъемный материал } 1996 \text { г., } \\
\text { сосуд № 2007/117; } \\
\text { нагар на керамическом сосуде }\end{array}$ & KIA-33928 & $6105 \pm 30$ & $5207-4940$ & $\begin{array}{l}49, \text { с. } 431- \\
433, \text { табл. } 1\end{array}$ \\
\hline $\begin{array}{l}\text { Вёкса III; ке- } \\
\text { рамика «се- } \\
\text { верного типа» } \\
\end{array}$ & $\begin{array}{l}\text { Раскоп } 2000 \text { г., слой } 6, \\
\text { кв. } 168-И ; \\
\text { грунт с древесными углями }\end{array}$ & Лe-5857 & $5700 \pm 700$ & $6099-3011$ & $\begin{array}{l}49, \text { с. } 431- \\
433, \text { табл. } 1\end{array}$ \\
\hline $\begin{array}{l}\text { Вёкса III; ке- } \\
\text { рамика «се- } \\
\text { верного типа» } \\
\end{array}$ & $\begin{array}{l}\text { Раскоп 1997 г., пласт 6; } \\
\text { кв. 166-И; } \\
\text { древесный уголь }\end{array}$ & ГИН-10182 & $5650 \pm 150$ & $4895-4081$ & $\begin{array}{l}49, \text { с. } 431- \\
433, \text { табл. } 1\end{array}$ \\
\hline \multicolumn{6}{|c|}{ Каргопольская культура } \\
\hline $\begin{array}{l}\text { Вёкса III, } \\
\text { слой } 6 \\
\end{array}$ & Грунт с древесными углями & ГИН-10180 & $5220 \pm 320$ & $\begin{array}{c}4801-3352 \mathrm{cal} \\
\mathrm{BC} \\
\end{array}$ & $\begin{array}{l}49, \text { с. } 431- \\
433, \text { табл. } 1 \\
\end{array}$ \\
\hline \multicolumn{6}{|c|}{ Черноборская группа } \\
\hline Прилукская & $\begin{array}{l}\text { Раскоп } 21988 \text { г.; очаг; } \\
\text { древесный уголь }\end{array}$ & Ле-4814 & $6350 \pm 60$ & $5469-5221$ & $\begin{array}{l}45, \text { с. } 334, \\
\text { табл. } 1\end{array}$ \\
\hline Прилукская & $\begin{array}{l}\text { Раскоп } 21988 \text { г.; очаг; } \\
\text { древесный уголь }\end{array}$ & Лe-4813 & $6680 \pm 70$ & $5710-5491$ & $\begin{array}{l}45, \text { с. } 334, \\
\text { табл. } 1\end{array}$ \\
\hline Прилукская & Керамика, прямое датирование & $\mathrm{Ki}-16174-1$ & $6170 \pm 90$ & $5320-4851$ & $\begin{array}{l}\text { 45, с. } 334, \\
\text { табл. } 1\end{array}$ \\
\hline Прилукская & Керамика, прямое датирование & $\mathrm{Ki}-16207$ & $6220 \pm 90$ & $5458-4937$ & $\begin{array}{c}45, \text { с. } 334, \\
\text { табл. } 1\end{array}$ \\
\hline \multicolumn{6}{|c|}{ Дутово 1 тип } \\
\hline Дутово 1 & Обожженная кость & ГИН-14009а & $6680 \pm 50$ & $5706-5512$ & $\begin{array}{l}45, \text { с. } 334, \\
\text { табл. } 1\end{array}$ \\
\hline \multicolumn{6}{|c|}{ Чужъяёльская культура } \\
\hline \begin{tabular}{|l|} 
Ваднюр I, \\
жилище № 7
\end{tabular} & $\begin{array}{l}\text { Уголь древесный, вентиляцион- } \\
\text { ный канал № } 1\end{array}$ & $\mathrm{IGAN}_{\mathrm{AMS}}-6107$ & $5090 \pm 20$ & 3909-3802 & - \\
\hline \begin{tabular}{|l|} 
Ваднюр I, \\
жилище № 7 \\
\end{tabular} & $\begin{array}{l}\text { Уголь древесный, вентиляцион- } \\
\text { ный канал № } 2\end{array}$ & ГИН-15616 & $4950 \pm 100$ & $3968-3627$ & - \\
\hline \multicolumn{6}{|c|}{ Нарвский тип керамики } \\
\hline Вёкса III & $\begin{array}{l}\text { Подъемный материал } 1996 \text { г., } \\
6 \text { участок поселения, } \\
\text { сосуд № 2007/118; нагар } \\
\text { на внутренней поверхности } \\
\end{array}$ & KIA-33926 & $5425 \pm 30$ & $4341-4239$ & $\begin{array}{l}49, \text { с. } 431- \\
433, \text { табл. } 1\end{array}$ \\
\hline Вёкса III & $\begin{array}{l}\text { Подъемный материал } 1996 \text { г., } \\
6 \text { участок поселения, } \\
\text { сосуд № 2007/118; нагар } \\
\text { на внешней поверхности }\end{array}$ & KIA-49796 & $5492 \pm 23$ & $4436-4267$ & $\begin{array}{l}49, \text { с. } 431- \\
433, \text { табл. } 1\end{array}$ \\
\hline
\end{tabular}


Карманов В.Н., Недомолкина Н.Г., Мельничук А.Ф.

В настоящее время доказуемо обособление памятников типа Чёрная Вадья в группу стоянок, которая могла быть оставлена носителями одной культуры. Документируются они контекстами стоянки Чёрная Вадья [38, с. 224-231; 7, с. 29-31], Угдым IA, IB; Пезмогты 4А и Керос [8, с. 153-168] на р. Вычегде и Чашкинское озеро V, VI и VIII (неопубликованные материалы раскопок В.П. Денисова) на р. Каме. Эти памятники - возможно разновременные следы пребывания небольших коллективов, которые можно экспонировать на один миграционный путь по верхнему течению р. Камы, притокам р. Вычегды, и самой Вычегде (от г. Березников Пермского края до границы Республики Коми и Архангельской области). Вероятно, дальнейшее изучение материалов Средней Волги, Вятки и Нижней Камы расширит географию этой индустрии и позволит определить степень сопряжения памятников типа Чёрная Вадья с известной волго-камской культурой накольчатой керамики. Имеющиеся данные по углям и керамике стоянок Чашкинское озеро VI и VIII [56, с. 155-158] датируют образцы из раскопок Е.Л. Лычагиной, которые в отличие от материалов В.П. Денисова, дали не сопоставимые с памятниками типа Черной Вадьи инвентари. Поэтому хронология рассмотренных памятников пока не определена и базируется на принципе синхронизации сходных явлений и, с большей степенью вероятности включает период первой половины VI тыс. до н.э.

Памятники типа Черноборской III представляют еще один своеобразный вид каменной индустрии [7, с. 31-38]. Свидетельства пребывания носителей этой традиции выявлены на рр. Ижме, Мезени и Северной Двине и, возможно на Вычегде (Чудгудоръяг) [26, с. $95-98 ; 34$, с. $16-26 ; 57$, с. $31-36 ; 58$, с. 44-45]. Полного соответствия каменной индустрии этого типа не найдено. Отдельные предметы могут быть обнаружены в коллекции Берёзовой Слободки II-III на Нижней Сухоне [40, с. 100, рис. 6], но это не способствует решению проблемы поиска истоков и дальнейшей судьбы носителей этой культуры.

Сопряженные по технико-типологическим показателям каменные индустрии сопровождает керамическая посуда разного облика. Так, контекст Конещелья содержит керамику, украшенную помимо ямчатых вдавлений скульптурным орнаментом в виде валиков [34, с. 19, рис. 2]. Небольшое количество обломков такой посуды выявлено на стоянке Прилукская [57, с. 19, рис. 5] и поселениях Вис I и II [24, с. 113 , рис. 22 , с. 208 , табл. XXIV). К сожалению, состояние керамики Черноборской III [26, с. 98] таково, что не дает оснований судить были ли на ней такие элементы или нет.

В результате критического анализа архивных источников установлено, что использовавшиеся ранее ${ }^{14} \mathrm{C}$ даты стоянки Прилукская (табл. 1) [44, с. $158 ; 45$, c. 334, табл. 1] определяют возраст очага, пространственная связь которого с основным комплексом стоянки слаба. Поэтому хронология этих памятников также базируется преимущественно на принципе синхронизации сходных явлений. Она может включать диапазон времени в рамках первой половины VI тыс. до н.э.

Не менее своеобразной является индустрия стоянки Дутово 1 [7, с. 26-28]. Этот контекст вообще пребывает в полном одиночестве: его соответствия отсутствуют и в самом регионе и за его пределами. За истекшие 20 лет с момента его первой публикации новые данные так и не появились. Истоки дутовской каменной индустрии следует искать в культурах раннего неолита центра Восточно-Европейской равнины, где были распространены традиции изготовления наконечников стрел на пластинах. Единственный реконструированный сосуд не орнаментирован и может быть по этому показателю сопряжен с любой культурой с ранней керамикой. Баночная форма емкости и скошенный внутрь венчик позволяют соотнести его с посудой стоянок Берёзовой Слободки II-III и VI на р. Сухоне [59, с. 403, рис. 2]. Это пока единственная полная аналогия.

Источник наших сведений о хронологии памятников этого типа в регионе - характеристики каменной индустрии и керамической посуды, определяющие их место в системе культур раннего неолита. Подтверждением этому служит и дата, полученная по обожженным костям лосям из контекста Дутово 1, позволяющая отнести бытование стоянки ко второй четверти VI тыс. до н.э.

\section{Средний период}

Временные рамки этого периода конец VI - V тыс. до н.э. В это время регион осваивается носителями трем известных культур: камской, льяловской и каргопольской.

Ареал камской культуры в это время сильно сокращается. Достоверные источники развитого неолита отсутствуют на большей территории СBE и могут быть представлены только двумя жилищами стоянки Хуторской $[28$, с. 34-71; 2, с. 21-31]. С большей степенью вероятности обломки керамической посуды можно выявить в разновременных коллекциях поселений Васюково II, Поздеевское озеро I и, возможно, в разведочных материалах стоянок Чирва II, на оз. Чусовском (северная окраина Пермского края) [12, с. 49-50]. При этом результаты радиоуглеродного анализа контекстов камской культуры пока неоднозначны. Датированные обломки древесных углей со стоянки Хуторской позволяют отнести их к позднему, а керамики - к среднему неолиту. При этом первая часть дат (табл. 1) представляет в основном данные раскопок 2006 г., а вторая - из раскопок 1954, 1975-1976 гг. [56, с. 154-158]. Еще одна дата по фрагменту керамики камской культуры из поселения Васюково II укладывается в конец V - начало IV тыс. до н.э. [56, с. 155].

Следы пребывания носителей льяловской культуры распространены гораздо обширнее: на севере они ограничены низовьями Печоры (г. Нарьян-Мар, Ненецкий АО), на северо-востоке - Тиманским Кряжем (Республика Коми), на востоке - оз. Чусовским (Пермский край). Картирование памятников льяловской культуры на СВЕ и анализ количественного и качественного состава керамической посуды на них подтверждают стремление её носителей занять озёра или ландшафты, прилегающие к ним. Однако наиболее информативные источники в регионе представляют остатки слабо углубленных жилищ в долине p. Вычегды (Эньты ІБ, Эньты III (жилища № 1 № 5), Пезмогты 1, 3, 4 и 5; Вад I (жилище № 1)) [31, с. $14-19 ; 32$, с. $66 ;$ 7, с. 45-54], р. Мезени (Кыстырью) [33, с. 31-36] и стоянки на берегах р. Выми 
(Половники II) [36, с. 132-144] и р. Вёксы (Вёкса-М и Вёкса III (слои 5 и 6)) [5, с. 79-87; 6, с. 12-18].

Архитектура сооружений проста, а интенсивность обитания в них, слаба, если судить по характеристике культуровмещающих отложений и компонентов структур, количеству инвентаря. Размеры жилищ позволяют сопоставить численность людей в каждом из коллективов, оставивших их, с элементарными, нуклеарными (малыми) и неразделенными, объединенными (большими) семьями. Малочисленность сравнительно некрупных озёр на такой обширной территории и низкая демографическая емкость таежных ландшафтов повысили и без того высокую мобильность носителей льяловских традиций. При этом в условиях крайне низкой плотности малочисленного населения возможности воспроизводства столь малых коллективов были крайне ограничены. Поэтому сценарии развития льяловской культуры формирования ее локальных вариантов или родственных ей культур - по примеру сопредельных территорий здесь не были реализованы или они очень ограничены в пространстве и времени. Например, можно обратить внимание на возможное непродолжительное ее развитие на поселениях вблизи наиболее крупных озёр региона (Вис I, II; Пижма I, II; Ружникова и др.).

Такое расселение в регионе, действительно, могло быть связано с сегментацией, но не племен, о которых писали А.Я. Брюсов и Г.М. Буров, а объединенных или неразделенных семей. Эти миграции имели цель поиска, освоения и дальнейшей эксплуатации незанятых кормовых территорий. При этом не исключена вероятность наличия циклов в хозяйстве этих семей сообразно сезонам. Но, судя по доступным источникам, такая цикличность в регионе, если и была, то поддерживалась непродолжительное время.

Хронология комплексов льяловской культуры на $\mathrm{CBE}$ установлена по аналогиям с материалами ее древнейших памятников центра Русской Равнины [60, с. $115 ; 61$, с. 94], а для некоторых контекстов региона также радиоуглеродным методом. Они позволяют сопоставить наиболее вероятный период бытования комплексов льяловского типа на СВЕ с первой пол. V тыс. до н.э. (табл. 1).

В настоящее время авторы имеют особые мнения о культурной атрибуции 2-го комплекса с гребенчатой керамикой Вёксы III (слой 8), сопряженного с контекстами жилищ Эньты ІБ, III на р. Вычегде. Н.Г. Недомолкина считает, что этот тип посуды сходен с материалами стоянок западной части Вологодской области (типа Тудозеро V, поздний этап), Восточного Прионежья и Карелии и обособляет его от памятников льяловского типа [6, с. 16]. В.Н. Карманов полагает, что этот тип керамической посуды сопровождает каменный инвентарь льяловской культуры и, судя по датировкам контекста слоя 8 поселения Вёкса III может документировать трансформацию верхневолжской керамической традиции в льяловскую.

Кроме того, не солидарны авторы в культурной атрибуции керамики т.н. «северных типов» [62, c. 44]. Н.Г. Недомолкина допускает возможность самостоятельного бытования в регионе ее носителей (Вёкса III (слой 7) [5, с. 79-87]. Напротив, В.Н. Карманов присоединяется к мнению В.В. Сидорова и А.В. Энговатовой, которые считают, что посуда такого вида входит среди прочих вариантов в состав льяловских комплексов [62, с. 44$)$.
К западу от СВЕ формируется каргопольская культура. Основной ее ареал - Восточное Прионежье или восточные окраины т.н. «Озёрного края». Каково ее генетическое и хронологическое соотношение с льяловской культурой - дело будущих исследований. Возможно, ее следует воспринимать как локальный вариант льяловской культуры, но для такого вывода необходимо специальное исследование каменного инвентаря памятников Восточного Прионежья. Наиболее информативные источники для ее изучения в регионе - это Вёкса-Л и Вёкса III (слой 6), которые к тому же определяют восточную границу этой культуры. Время бытования этих комплексов - вторая четверть V - третья четверть IV тыс. до н.э. - обосновано только единичной датой Вёксы III (слой 6), к сожалению, имеющей очень широкий доверительный интервал (табл. 1).

\section{Поздний период}

Вторая половина V - первая половина IV тыс. до н.э. - наиболее скудно обеспеченное источниками время. На СВЕ нет ни одного достоверного источника о дальнейшем развитии в регионе льяловской культуры, носители которой в этот период оседают в освоенных озёрных котловинах за пределами региона. Нет следов населения камской культуры на финальном этапе ее развития. По результатам исследований внежилищного контекста Хуторской стоянки в 2006 г. получены данные радиоуглеродного анализа, свидетельствующие о протяженности традиций камской культуры до второй половины V - первой половины IV тыс. до н.э. Но на территории CBE источники по этому периоду крайне скудны и неинформативны.

Пока единственный достоверный источник этого периода - вычегодское поселение Ваднюр I (жилище № 7) чужъяёльской культуры. По этому контексту получены две синхронные независимые даты, сделанные по образцам из двух компонентов структуры и методами AMS датирования и конвенционального радиоуглеродного анализа в разных лабораториях. Они позволяют датировать его бытование первой половиной IV тыс. до н.э. (табл. 1). Ранее В.С. Стоколос был уверен в финальнонеолитическом возрасте части контекстов этой культуры [63, с. 218, 219], но его аргументация не убеждала исследователей [44, c. 155,156$]$. А широкий разброс радиоуглеродных дат контекста Чойновты I не позволяет использовать их для определения хронологии памятников этого типа на р. Мезени [64, с. 119, 120].

Истоки чужъяёльского способа обработки кремня в регионе отсутствуют. Можно предположить два источника формирования такой традиции обращения с кремнем. Первый наиболее вероятный - Западная Сибирь, например, памятники атымьинского типа [65, с. 192-193]. Второй никогда исследователями не рассматривавшийся и менее вероятный - Кольский п-ов. При этом учитывается его территориальная близость p. Мезени, в долине которой расположены практические все информативные источники для изучения чужъяёльской культуры. Этот регион нужно иметь в виду и с целью поиска характерной черты чужъяёльского домостроительства - вентиляционных каналов типичного компонента жилой структуры типа грессбакен Норвегии и Кольского п-ова [66, с. 612, 613].

Чужъяёльская керамическая традиция также не имеет корней в культурах СВЕ предшествующего времени. Ее наиболее вероятные истоки - это культуры т.н. гребенчатого геометризма Западной Сиби- 
Карманов В.Н., Недомолкина Н.Г., Мельничук А.Ф.

ри и Урала, в частности, наиболее близкой территориально ясунской культуры [67, с. 122-123]. Однако все эти традиции исследователи относят к энеолиту, а даты контекста жилища № 7 поселения Ваднюр I пока не соответствуют этим представлениям. Яркая чужьяёльская культура не имеет явного продолжения в более поздний период. Скорее всего, ее создатели растворились в среде населения гаринской культуры, обладавшими более высокими технологиями обработки кремня и владевшими навыками металлообработки.

В настоящее время достоверно не определена принадлежность к какому-либо из периодов неолита памятников с керамической посудой, не имеющих однозначных контекстов. Таковы, прежде всего, местонахождения с т.н. «каргопольским» или пинежско-вычегодским типом керамики Вис I, II [24, с. 95]; Явроньга I [25, с. 38-43, 50, 51]; Усть-Комыс I [68, c. 110-112]. Также неясна пока ситуация нахождения «висского» типа керамики. Основная масса ее найдена на поселении Вис I и II [24, с. 77, 78], возможно, Пижме II [69, с. 36, рис. 6]. Единичные фрагменты выявлены в комплексах поселения Васюково II и Поздеевское озеро I (оз. Чусовское) [11, с. 68]. С позиций критики источников вся совокупность этой посуды пока может играть роль исследовательской группировки керамики по некоторым близким показателям: примесь мелкотолченой дресвы, легкий изгиб губы сосуда наружу, а главное, «шагающая гребенка» в сочетании с ямками или ямчатыми вдавлениями. При этом Г.М. Буров сопрягал с ней и обломки типично льяловских сосудов, гибридный характер которых в таком виде недоказуем [24, с. 71, рис. 15: 7, 11-17, рис. 16: 4, 7; с. 191, табл. VII: 2, 3]. Среди подъемного материала на поселении Вёкса III выявлен сосуд нарвского типа [49, с. 427, 428, рис. 2], по нагару с которого были получены радиоуглеродные даты (табл. 1). Все эти типы посуды и памятников - пока лишь следы некоего эфемерного населения, которые нужно иметь в виду в исследованиях, но не следует решать на основании этих неинформативных источников вопросы таксономического статуса памятников или судьбы культур неолита.

Керамика стоянки Каджером в долине р. Вашки (левый приток р. Мезени) [70, с. 61-65], представленная сосудом, украшенным гребенчатым штампом в технике протаскивания, также не находит аналогий в регионе и на сопредельных территориях. А каменный инвентарь малочислен и не информативен для его полной и корректной характеристики. Однако это объясняется малой площадью исследования (16 кв. м), и, возможно, дальнейшие раскопки позволят установить культурно-хронологическую атрибуцию памятника.

Трансформация культур

Для всех описанных выше культур характерно их упрощение по мере распространения на север и северо-восток. Эта трансформация выражается в сокращении численности орудий и керамической посуды в коллекциях; в ограничении ассортимента инвентаря. Например, единичны рубящие орудия из некремневых пород, ничтожно количество предметов неутилитарного назначения. Вместе с тем на некоторых памятниках найдено большое количество охотничьего вооружения из кремня (Черноборская III, Эньты IA); сравнительно многочисленные остатки промысловой фауны таежной зоны. Практически полностью исчезают из контекстов свидетельства рыбо- ловства. Это указывает на рост значения охоты в системах жизнеобеспечения, несмотря на прочие различия культур.

В части керамической посуды упрощаются орнаментальные схемы; отсутствуют или крайне малочисленны некоторые распространенные южнее элементы орнаментации (например, треугольный накол и насечки). Также ограничен набор техник орнаментирования: шагание, прочерчивание, протаскивание, скульптурные элементы крайне редки на неолитической керамике крайнего северо-востока Европы.

Показательно и то, что углубленные жилища неолита известны преимущественно в этой части региона, в долинах Вычегды и Мезени. Большая часть контекстов этого периода представлена именно такими местами обитания. Напротив, к юго-западу и югу такие объекты редки. Во всей каргопольской культуре выявлено всего две постройки на Андозеро 2 и Кубенино [30, с. 42-45, 61, 62]. Льяловскую культуру в Волго-Окском междуречье представляют в основном остатки наземных построек [71, с. 106 108]. В камской культуре в Прикамье представлено всего три углубленных жилища на стоянках Хуторской (два объекта) и Усть-Залазнушка (объект). Вполне возможно, что эта информация искажена степенью изученности отдельных частей региона (отсутствие памятников неолита на большей части Кировской области и центральной части Архангельской области) или негативным воздействием антропогенных факторов (на средней Каме - Камское водохранилище, более интенсивное использование территорий льяловской культуры в последующее время и т.п.). Ведь южнее в Камско-Вятском междуречье и в Среднем Поволжье изучено большое количество углубленных построек неолита [54, с. 82-91; 72 , c. $48-50,84-100]$.

\section{Заключение}

На CBE частично изучены ареалы известных культур неолита Восточной Европы - верхневолжской, камской, льяловской и родственной ей каргопольской. В зависимости от пространственного соотношения с ними памятники региона представляют их северо-восточные или северные периферии. При сравнении контекстов провинций культур и их основных территорий мы наблюдаем сходство их инвентарей на фоне различий в количестве памятников; их плотности; мощности культуровмещающих отложений на них; количественных и некоторых качественных характеристик инвентарей. По этим показателям источники СВЕ свидетельствуют о кратковременности бытования здесь их традиций, а, значит, и их носителей. Тоже самое можно сказать о выявленных в регионе фрагментах культур, исходные территории формирования которых пока достоверно не определены. Они представлены ранненеолитическими памятниками типа Дутово 1, Черноборской III, Эньты ІА и Черной Вадьи. Их следы теряются в пространстве и времени не только из-за высокой мобильности малочисленных групп населения, но и источниковедческих проблем. На известных опорных памятниках CBE удается проследить особенности камнеобработки на уровне семейных традиций, а материалы более плотно заселенных сопредельных территорий такой возможности пока не дают. Поэтому изучены только отрезки путей миграций носителей разнообразных, преимущественно ранненеолитических культур неолита. 
Характеристики свидетельств о культурах неолита на СВЕ пока подтверждают данные о том, что их в регионе периодически представляют небольшие группы населения. Эти коллективы соизмеримы с элементарными и объединенными (неразделенными) семьями. Наиболее вероятно, что следы их пребывания на большей части региона были связаны с поиском неосвоенных кормовых территорий, их освоением и кратковременной эксплуатацией. Гораздо меньше свидетельств наличия миграций в рамках выполнения хозяйственных циклов сообразно сезонам. На большей территории СВЕ за исключением ее самых юго-западных и юго-восточных частей, не было условий для длительного проживания первобытного населения и формирования местных традиций, поскольку малочисленность таких дисперсных групп людей не могла обеспечить их самовоспроизводство. Лишь в энеолите на СВЕ появляются более многочисленные носители гаринской культуры. Их возможные связи с населением чужъяёльской культуры и/или пока эфемерными группами из Западной Сибири формируют местные культуры, например, лебяжскую. Однако их носители еще долгое время, вплоть до эпохи железа, вели «неолитический» образ жизни и были рассредоточены в регионе очень мобильными дисперсными группами, система жизнеобеспечения которых базировалась преимущественно на охоте.

\section{Перспективы}

Авторы надеются на продуктивность дальнейших коллективных исследований неолитических памятников без учета современных административных или других искусственных границ. Перспективна попытка обновления представлений о социальных системах неолитических охотников-собирателей и определения в их культуре места каждой категории доступных инвентарей, прежде всего, каменных и керамической посуды. Ведь именно это определяет природу археологических источников и влияет на понимание конкретных археологических ситуаций. Такие данные позволят приблизиться к построению адекватной модели формирования неолитических культур, их развития и дальнейших судеб на более обширной территории Восточной Европы и Урала.

\section{Список литературы:} $379 \mathrm{c}$.

1. Неолит Северной Евразии. М.: Наука, 1996.

2. Денисов В.П., Мельничук А.Ф. Второе жилище Хуторской стоянки // Неолитические памятники Урала. Свердловск: УрО АН СССР, 1991. С. 21-31.

3. Недомолкина Н.Г. Неолитические комплексы поселений Вёкса и Вёкса III бассейна верхней Сухоны и их хронология // Проблемы хронологии и этнокультурных взаимодействий в неолите Евразии. СПб.: ИИМК РАН, 2004. С. 265-279.

4. Недомолкина Н.Г. Неолит Верхней Сухоны. Афтореф. дис. ... канд. ист. наук. СПб., 2007. 22 с.

5. Недомолкина Н.Г. К вопросу о керамике «северных типов» в бассейне Верхней Сухоны // Археология Восточноевропейской лесостепи: сборник матлов междунар. науч.-практ. конф., посв. 80-летию со дня рожд. А.Г. Николаенко (г. Белгород, 14-16 декабря 2017 года) / отв. ред. В.А. Сарапулкин. Белгород: ИД «Белгород» НИУ «БелГУ», 2018. С. 79-87.

6. Недомолкина Н.Г., Иванищева М.В. Бассейн реки Сухоны в развитом неолите // Ученые записки Петрозаводского государственного университета. 2015. № 1 (146). C. 12-18.
7. Карманов В.Н. Неолит европейского СевероВостока. Сыктывкар: Изд-во Коми НЦ УрО РАН, 2008. 226 c.

8. Карманов В.Н. Исследование ранненеолитической стоянки Керос на средней Вычегде // От Балтики до Урала: изыскания по археологии каменного века. Сыктывкар: Изд-во Коми НЦ УрО РАН, 2014. C. $153-168$.

9. Карманов В.Н. Стоянка Зубово - памятник с накольчатой керамикой на Мезени (Архангельская обл.) // Проблемы изучения эпохи первобытности и раннего средневековья лесной зоны Восточной Европы: к 60-летию А.В. Уткина. Вып. IV. Иваново: Издатель Ольга Епишева, 2015. С. 66-71.

10. Карманов В.Н., Недомолкина Н.Г. Неолит северо-востока Русской Равнины: современные концепции // IV Северный археологический конгресс: доклады. 19-23 октября 2015 г., г. Ханты-Мансийск. Екатеринбург: Институт истории и археологии УрО PAH, 2015. C. 84-104.

11. Денисов В.П., Мельничук А.Ф., Бурмасов М.С., Чурилов Э.В. Неолит Северного Прикамья. Итоги изучения // Историко-культурное наследие - ресурс формирования социально-исторической памяти гражданского общества (XIV-e Бадеровские чтения): мат-лы всерос. науч.-практ. конф. Ижевск: Изд-во «Удмуртский университет», 2013. С. 66-71.

12. Мельничук А.Ф., Чурилов Э.В., Карманов В.Н. Неолит бассейна р. Вишеры Пермского края // XXI Уральское археологическое совещание, посв. 85летию со дня рожд. Г.И. Матвеевой и 70-летию со дня рожд. И.Б. Васильева: мат-лы всерос. науч. конф. с междунар. участием. Самара: Изд-во СГСПУ, 2018. C. $49-50$.

13. Никифорова Л.Д. Динамика ландшафтных зон голоцена Северо-Востока европейской части СССР // Развитие природы территории СССР в позднем плейстоцене и голоцене. М.: Наука, 1982. С. 154-162.

14. Смирнова Т.И. Основные изменения растительности севера Печорской низменности в четвертичное время (по палинологическим данным): автореф. дис. ... канд. биол. наук. М., 1971. 19 с.

15. Марченко Т.И. Палеогеография голоцена Европейского Северо-Востока по данным диатомового анализа: дис. ... канд. геол.-минерал. наук. Сыктывкар, 1997. 143 c.

16. Марченко Т.И., Дурягина Д.А. Условия формирования голоценовых отложений в бассейнах рек Вычегды и Большой Роговой (по данным диатомового и спорово-пыльцевого анализов). Сыктывкар: Коми НЦ УрО РАН, 1996. 44 с.

17. Жуйкова И.А. Условия формирования аллювиальных отложений среднего течения р. Вятки // Структура, вещество, история литосферы ТиманоСевероуральского сегмента: информационные матлы 10-й науч. конф. Сыктывкар: Геопринт, 2001. С. $68-70$.

18. Недомолкина Н.Г., Пицонка Х., Лоренц С., Шмёлке У. Новые археологические, остеологические и геоморфологические исследования на комплексе многослойных поселений Вёкса в бассейне Верхней Сухоны // Тверской археологический сборник. Вып. 10. T. I: мат-лы V Тверской археологической конф. и 16го и 17-го заседаний науч.-метод. семинара «Тверская земля и сопредельные территории в древности». Тверь: ООО «Изд-во «Триада», 2015. С. 74-84.

19. Карманов В.Н. Неолитическое население на европейском Северо-Востоке: обитание или пребы- 
Карманов В.Н., Недомолкина Н.Г., Мельничук А.Ф.

вание? // Первобытные древности Евразии. К 60летию Алексея Николаевича Сорокина. М.: ИА РАН, 2012. С. 419-446.

20. Фосс М.Е. Древнейшая история Севера Европейской части СССР // Материалы и исследования по археологии СССР. М.: Изд-во АН СССР, 1952. № 29. 278 с.

21. Фосс М.Е. Неолитические культуры Севера Европейской части СССР // Советская археология. 1947. T. IX. C. 29-46.

22. Гурина Н.Н. Некоторые новые данные о заселении Севера европейской части СССР // Советская археология. 1957. Т. II. С. 115-120.

23. Бадер О.Н. Жертвенное место под камнем Писаным на р. Вишере // Советская археология. 1954. T. XXI. C. 241-258.

24. Буров Г.М. Древний Синдор (из истории племен Европейского Северо-Востока в VII тысячелетии до н.э. - I тысячелетии н.э.). М.: Наука, 1967. 220 с.

25. Буров Г.М. Археологические культуры Севера европейской части СССР (Северодвинский край): учебное пособие для студентов-историков. Ульяновск: Ульяновский государственный педагогический институт, 1974. 120 с.

26. Лузгин В.Е. Мезолит и ранний неолит в долине р. Ижмы (бассейн средней Печоры) // Этнокультурные общности лесной и лесостепной зоны европейской части СССР в эпоху неолита. Л.: Наука, 1973. С. 95-98 (Материалы и исследования по археологии СССР; № 172).

27. Лузгин В.Е. Поселение Ружникова на Косминских озерах и вопросы неолита Европейского Северо-Востока // Археологические исследования в бассейне Печоры. Сыктывкар: Коми филиал АН СССР, 1973. С. 22-34 (Материалы по археологии Европейского Северо-Востока; Вып. 5).

28. Денисов В.П. Хуторская неолитическая стоянка // Ученые записки Пермского государственного университета. Т. ХІІ. Вып. 1. Пермь, 1960. С. 34-71.

29. Денисов В.П. Свидетели древности - камень, бронза и железо // На западном Урале. Пермь: Пермский областной краеведческий музей, 1969. Вып. 5. C. $312-327$.

30. Ошибкина С.В. Неолит Восточного Прионежья. М.: Наука, 1978. 231 с.

31. Логинова Э.С. Поселение Эньты I // Археологические памятники эпохи палеометалла в Северном Приуралье. Сыктывкар: Коми филиал АН СССР, 1978. С. 3-23 (Материалы по археологии Европейского Северо-Востока; Вып. 7).

32. Логинова Э.С. Поселения эпохи неолита на Средней Вычегде // Материалы VI международного конгресса финно-угроведов. Т. 1. М.: Наука, 1989. С. 66.

33. Стоколос В.С. Первый неолитический памятник на Мезени // Археологические памятники Печоры, Северной Двины и Мезени. Сыктывкар: Коми филиал АН СССР, 1977. С. 31-36 (Материалы по археологии Европейского Северо-Востока; Вып. 6).

34. Стоколос В.С. Поселение Конещелье - первый на Мезени памятник с накольчатой керамикой // Материальная и духовная культура населения Европейского Северо-Востока. Сыктывкар: Коми НЦ УрО АН СССР, 1987. С. 16-26. (Труды Института языка, литературы и истории Коми филиала АН СССР; Вып. 39).

35. Верещагина И.В. Мезолит и неолит крайнего Европейского Северо-Востока. СПб.: Петербургское востоковедение, 2010. 232 с.
36. Косинская Л.Л. Неолитическая стоянка-мастерская на Выми // Проблемы этногенетических исследований Европейского Северо-Востока: межвуз. сб. науч. тр. Сыктывкар: Сыктывкарский ун-т, 1982. С. $132-144$.

37. Косинская Л.Л. Неолитическая стоянка Кочмас на нижней Вычегде // Неолитические памятники Урала: сб. науч. тр. Свердловск: УрО АН СССР, 1991. C. 4-20.

38. Косинская Л.Л. К проблеме генезиса черноборской археологической культуры (по материалам поселения Черная Вадья на Нижней Вычегде) // Тверской археологический сборник. Вып. 5. Тверь: Тверской государственный объединенный историко-архитектурный и литературный музей, 2002. С. 224-231.

39. Косинская Л.Л. Поселение Ревью I // Проблемы археологического изучения северо-востока Европы. Сыктывкар: ИЯЛИ Коми НЦ УрО РАН, 2018. С. 39-54 (Материалы по археологии европейского Северо-Востока; Вып. 20).

40. Иванищева М.В. Ранний неолит Нижнего Посухонья // Археология: история и перспективы Вып. 2. Ярославль: Рыбинский Дом печати, 2006. C. $85-105$.

41. Макаров Н.А., Захаров С.Д., Бужилова А.П. Средневековое расселение на Белом озере. М.: Яз. рус. культуры, 2001. 495 с.

42. Буров Г.М. Крайний Северо-Восток Европы в эпоху мезолита, неолита и раннего металла: автореф. дис. ... д-ра ист. наук. Новосибирск, 1986. 37 с.

43. Косинская Л.Л. Мезолит - ранняя бронза бассейна Нижней Вычегды: автореф. дис. ... канд. ист. наук. Л., 1988. 24 с.

44. Косинская Л.Л. Неолит // Археология Республики Коми. М.: ДиК, 1997. С. 146-212.

45. Karmanov V.N., Zaretskaya N.E., Lychagina E.L. Neolithic Dispersal in Far Northeast Europe: Ways and Chronology // Radiocarbon. 2012. Vol. 54 (3). P. 331-339.

46. Karmanov V.N., Zaretskaya N.E., Volokitin A.V. Another Way of Early Pottery Distribution in Eastern Europe? Case Study of the Pezmog 4 Site, European Far Northeast // Radiocarbon. 2014. Vol. 56, № 2. P. 733-741.

47. Бадер О.Н. Волго-камская этнокультурная область эпохи неолита // Этнокультурные общности лесной и лесостепной зоны европейской части СССР в эпоху неолита. Л.: Наука, 1973. С. 99-106 (Материалы и исследования по археологии СССР; № 172).

48. Верещагина И.В. Мезолит и неолит крайнего Европейского Северо-Востока: автореф. дис. ... канд. ист. наук. Л., 1989. 22 с.

49. Недомолкина Н., Пицонка Х. Регион Верхней Сухоны в раннем и среднем неолите по результатам радиоуглеродной хронологии (по материалам поселений Вёкса I, Вёкса III) // Радиоуглеродная хронология эпохи неолита Восточной Европы VII-III тысячелетия до н.э. Ч. 6. Смоленск: Свиток, 2016. 425-443.

50. Энговатова А.В., Жилин М.Г., Спиридонова Е.А. Хронология верхневолжской ранненеолитической культуры (по материалам многослойных памятников Волго-Окского междуречья) // Российская археология. 1998. № 2. С. 11-21.

51. Hartz S., Kostyleva E., Piezonka H., Terberger T., Zhilin M.G., Tsydenova N. Hunter-Gatherer Pottery And Charred Residue Dating: New Results On Early Ceramics In The North Eurasian Forest Zone // Radiocarbon. 2012. 54 (3-4). P. 1033-1048.

52. Долбунова Е.В., Кулькова М.А., К Костылева Е.Л., Мазуркевич А.Н. Новые данные по хроноло- 
гии ранненеолитических материалов памятника Сахтыш ІІа // Радиоуглеродная хронология эпохи неолита Восточной Европы VII-III тысячелетия до н.э. Ч. 2. Смоленск: Свиток, 2016. С. 159-170.

53. Недомолкина Н.Г. Геометрические микролиты ранненеолитического поселения Вёкса III (Верхняя Сухона): проблема культурно-хронологической принадлежности // От Балтики до Урала: изыскания по археологии каменного века. Сыктывкар: Изд-во Коми НЦ УрО РАН, 2014. С. 147-153.

54. Гусенцова Т.М. Мезолит и неолит КамскоВятского междуречья: монография. Ижевск: Изд-во Удм. ун-та, 1993. 240 с.

55. Косинская Л.Л. Ранняя гребенчатая керамика в неолите Зауралья // Уральский исторический вестник. № 2 (43). 2014. С. 30-40.

56. Лычагина Е.Л. Радиоуглеродная хронология неолита Верхнего и Среднего Прикамья и КамскоВятского междуречья // Радиоуглеродная хронология эпохи неолита Восточной Европы VII-III тысячелетия до н.э. Ч. 2. Смоленск: Свиток, 2016. С. 140-159.

57. Верещагина И.В. Ранний неолит на Северной Двине // Археологические памятники Печоры, Северной Двины и Мезени. Сыктывкар: Коми филиал АН СССР, 1977. С. 31-36 (Материалы по археологии Европейского Северо-Востока; Вып. 6).

58. Логинова Э.С. Поселение Чудгудорьяг // Взаимодействие культур Северного Приуралья в древности и средневековье. Сыктывкар: Коми НЦ УрО РАН, 1993. С. 41-59 (Материалы по археологии Европейского Северо-Востока; Вып. 12).

59. Иванищева М.В., Кулькова М.А., Иванищева Е.А. Радиоуглеродная хронология раннего неолита Нижней Сухоны и Юго-Восточного Прионежья // Радиоуглеродная хронология эпохи неолита Восточной Европы VII-III тысячелетия до н.э. Ч. 6. Смоленск: Свиток, 2016. С. 397-409.

60. Энговатова А.В. Хронология поселения Воймежное 1 и вопросы периодизации неолита Русской Равнины // Древние охотники и рыболовы Подмосковья (по материалам многослойного поселения эпохи камня и бронзы Воймежное I). М.: ИА РАН, 1997. С. $104-120$.

61. Энговатова А.В. Хронология эпохи неолита Волго-Окского Междуречья // Хронология неолита Восточной Европы: тез. докл. междунар. конф., посв. памяти Н.Н. Гуриной. Санкт-Петербург, 27 ноября 2 декабря 2000 г. СПб.: ИИМК РАН, 2000. С. 94.

62. Жилин М.Г., Костылева Е.Л., Уткин А.В., Энговатова А.В. Мезолитические и неолитические культуры Верхнего Поволжья. По материалам стоянки Ивановское VII. М.: Наука, 2002. 245 с.

63. Стоколос В.С. Энеолит и бронзовый век // Археология Республики Коми. М.: ДиК, 1997. С. 213-313.

64. Карманов В.Н. Проблемы хронологии энеолита крайнего северо-востока Европы // Уральский исторический вестник. 2018. № 3 (60). С. 115-125.

65. Кокшаров С.Ф. Памятники энеолита севера Западной Сибири. Екатеринбург: Изд-во НПМП «Волот», 2009. $272 \mathrm{c.}$

66. Шумкин В.Я., Колпаков Е.М., Тарасов А.Ю. Поселение Завалишина-5 на берегу Баренцева моря // Первобытные древности Евразии. К 60-летию Алексея Николаевича Сорокина. М.: Изд-во ИА РАН, 2012. С. 611-622.

67. Васильев Е.А., Глызин И.П. Ясунская энеолитическая культура севера Западной Сибири // Культура как система в историческом контексте: опыт Западно-Сибирских археолого-этнографических совещаний: мат-лы XV междунар. Западно-Сибирской археолого-этнографической конф. / отв. ред. М.П. Чёрная. Томск: Аграф-Пресс, 2010. С. 121-124.

68. Семенов В.А., Несанелене В.Н. Европейский Северо-Восток в эпоху бронзы (по материалам раскопок Сыктывкарского университета): учебное пособие. Сыктывкар: Сыктывкарский ун-т, 1997. 172 с.

69. Лузгин В.Е. Неолитические стоянки Центрального Тимана // Поселения каменного и меднобронзового века на Печоре и Усе. Сыктывкар: Коми филиал АН СССР, 1973. С. 24-46 (Материалы по археологии Европейского Северо-Востока; Вып. IV).

70. Волокитин А.В., Карманов В.Н. Каджером памятник позднего неолита на Удоре // Геолого-археологические исследования в Тимано-Североуральском регионе: мат-лы І-й науч. конф. ФЦП «Интеграция». Сыктывкар: Геопринт, 1998. С. 61-65.

71. Сидоров В.В. Льяловские жилища // Неолитические культуры Восточной Европы: хронология, палеоэкология, традиции: мат-лы междунар. науч. конф., посв. 75-летию В.П. Третьякова. СПб.: ИИМК PAH, 2015. C. 106-108.

72. Никитин В.В. Каменный век Марийского края // Труды Марийской археологической экспедиции. T. IV. Йошкар-Ола: МарНИИ, 1996. 180 с.

Исследование выполнено в рамках научно-исследовательской работы "Археологическое наследие европейского северо-востока России: выявление, научное описание и систематизация", №ГP AAAA-A17-117021310069-5.

\section{MODERN CONCEPTS OF NEOLITHIC CULTURES IN NORTHEASTERN EUROPE}

(C) 2019

Karmanov Viktor Nikolayevich, candidate of historical sciences, head of Preservation and Popularization of Archaeological Heritage Sector Institute of Language, Literature and History of Komi Scientific Centre of Ural Branch of Russian Academy of Sciences (Syktyvkar, Russian Federation)

Nedomolkina Nadezhda Gennadyevna, candidate of historical sciences, leading researcher of Funds Department Vologda State Museum-Preserve of History, Architecture and Decorative Arts (Vologda, Russian Federation)

Melnichuk Andrey Fyodorovich, candidate of historical sciences, associate professor of Ancient and Modern History Department

Perm State National Research University (Perm, Russian Federation)

Abstract. The authors summarize and systematize data on Neolithic cultures in northeastern Europe. It is a modern territory of the Komi Republic, the northern part of the Perm Territory, the Vologda and Arkhangelsk Regions, and the Nenets Autonomous Okrug. Based on the critical analysis of evidences, their analysis and interpretation, the authors present their views on the features of the formation, development and fate of the Neolithic cultures of the re- 
gion. It has been established that the studied region contains northern and northeastern provinces of the famous cultures of the early and middle Neolithic of Eastern Europe: Verkhnevolzhskaya, Kamskaya, Lyalovskaya and Kargopolskaya. In addition, fragments of some cultures were identified. Their initial areas of formation are not yet reliably determined. They are represented by early Neolithic sites such as Dutovo 1, Chernoborskaya III, Enty IA and Chyornaya Vadya. Some types of pottery without a specific context document the presence of population groups in northeastern Europe whose status has not been defined yet. The authors suggest that the formation of Neolithic cultures in the region is associated with the search for undeveloped feeding areas, their development and short-term exploitation by small groups of people commensurate with elementary or unified families. Until the Eneolithic in the greater territory of northeastern Europe the conditions for long-term residence of the Neolithic population were absent as well as the formation of local traditions.

Keywords: archaeology; Neolithic; northeastern Europe; paleogeography; archaeological culture; archaeological data; archaeological context; archaeological reconnaissance; archaeological excavations; migrations; stone implements; pottery; site; settlement; multi-layered site; subterrain dwelling; concentration zone; fireplace.

УДК 902

DOI 10.24411/2309-4370-2019-12212

Статья поступила в редакцию 20.12.2018

\section{МОРСКАЯ ОХОТА И РЫБОЛОВСТВО НА ПОБЕРЕЖЬЕ СЕВЕРНОЙ ФЕННОСКАНДИИ ДО РУБЕЖА ЭР}

(C) 2019

Киселева Алевтина Михайловна, магистрант кафедры археологии

Мурашкин Антон Игоревич, старший преподаватель кафедры археологии

Санкт-Петербургский государственный университет (2. Санкт-Петербург, Российская Федерация)

Аннотация. Археологические свидетельства морского промысла на побережье Баренцева моря датируются временем примерно от $5000 \mathrm{cal}$ ВС до рубежа эр, что охватывает эпохи неолита, раннего металла и раннего железного века. К специализированным орудиям морской охоты и рыболовства относятся костяные и роговые наконечники гарпунов, рыболовные крючки и наконечники острог. На основе анализа совстречаемости типов орудий в замкнутых и полузамкнутых комплексах (жилища, раковинные кучи, погребения) было выделено четыре периода развития костяного инвентаря. С опорой на радиоуглеродные датировки установлены следующие хронологические границы периодов: А - 5000-2500 cal BC, В - 2500-1600 cal BC, С 1500-1100 cal BC, D - 900 cal BC-0 cal BC/AD. Основными промысловыми животными были тюлени и китообразные. Охота на них дополнялась ловлей атлантической трески и тресковых. Процентное соотношение костей животных в датированных комплексах показывает, что с $2500 \mathrm{cal} \mathrm{BC} \mathrm{в} \mathrm{хозяйстве} \mathrm{заметно} \mathrm{возрастает}$ роль охоты на тюленей и на китообразных. Это совпадает с появлением в промысловом инвентаре поворотных гарпунов. В раннем железном веке (после $900 \mathrm{cal} \mathrm{BC)} \mathrm{роль} \mathrm{морского} \mathrm{промысла} \mathrm{также} \mathrm{остается} \mathrm{высокой;}$ на прибрежных памятниках переориентация хозяйства на наземные ресурсы по археологическим данным не прослеживается.

Ключевые слова: Северная Фенноскандия; Кольский полуостров; Северная Норвегия; неолит; эпоха раннего металла; ранний железный век; периодизация; хронология; морская охота; рыболовство; костяной инвентарь; рыболовные крючки; наконечники гарпунов; остроги; фаунистический анализ; охотничья добыча; ластоногие; китообразные; рыба.

\section{Введение}

Морской промысел является одним из самых стабильных видов экономики присваивающего типа [1, с. $1-9 ; 2$, с. $34-84,165-191 ; 3]$. В эпоху неолита на побережье Баренцева моря (северные провинции Норвегии и Мурманская область РФ) сформировалась единая культура охотников на морского зверя. На протяжении периода раннего металла и раннего железного века в культуре (прежде всего материальной) прибрежного населения происходят многочисленные изменения, но ее экономической основой на протяжении тысячелетий остается рыболовство и морская охота. Основными источниками, позволяющими охарактеризовать хозяйство древнего населения от каменного до раннего железного века (5000 cal BC$\mathrm{BC} / \mathrm{AD})$, являются фаунистические остатки и специализированные промысловые орудия из кости и рога.

Поскольку русскоязычная аудитория не знакома с периодизационными схемами, распространенными в Северной Фенноскандии, необходимо сделать небольшое отступление. Наиболее дробная и обосно- ванная периодизация в регионе создана для территории Финнмарка [4, p. 14]. Согласно ей, период позднего каменного века (сопоставим с периодом неолита в российской литературе) датируется 5000-1800 cal BC. Период раннего металла делится на две фазы - текстильной керамики (1800-900 cal BC) и щельмой (900 cal BC-BC/AD). В последнюю фазу появляются первые железные орудия, что позволяет сопоставлять ее с ранним железным веком для СевероЗапада России.

Первые памятники с остатками фауны и разнообразными костяными и роговыми изделиями в Северо-Восточной Норвегии - поселения раннего железного века Местешан и Маккола на острове Щельмой - были исследованы и опубликованы еще в начале 20 века. [5; 6]. К середине двадцатого столетия свидетельства специализированного морского промысла, происходящие из жилищ, раковинных куч, погребений неолита - раннего железного века, становятся все более многочисленными. В 1940-е годы Г. Йессинг создал первую классификацию каменного 